\title{
Công ty TNHH MTV Trà Tâm Lan đạt danh hiệu Hàng Việt Nam chất lượng cao
}

Đến dự có ông Nguyễn Quân- Bộ trưởng Bộ Khoa học và Công nghệ, bà Hồ Thị Thoa- Thứ trưởng Bộ Công Thương, ông Bùi Văn Quyền- Cục trưởng Cục Công tác phía Nam Bộ Khoa học và Công nghệ, bà Nguyễn Thị Hồng- Phó Chủ tịch UBND TP.Hồ Chí Minh, bà May Amiel- sáng lập viên, Giám đốc Trung tâm hỗ trợ doanh nghiệp cộng đồng thuộc SIT (Israel).

Bà Nguyễn Thị Hồng- Phó Chủ tịch UBND TP.Hồ Chí Minh trao Giấy chứng nhận danh hiệu HVNCLC năm 2014 cho bà Võ Thị Lấn (thư 2 tù trái qua)- Giám đốc Công ty TNHH MTV Trà Tâm Lan.

Tại buổi lễ, Hội doanh nghiệp HVNCLC đã tôn vinh 476 doanh nghiệp đạt danh hiệu HVNCLC năm 2014 do người tiêu dùng bình chọn; khen thưởng 17 doanh nghiệp có thành tích đổi mới sáng tạo; chúc mừng 42 doanh nghiệp 18 năm liền đạt HVNCLC.

Công ty TNHH MTV Trà Tâm Lan (ấp Khởi Trung, xã Cầu Khởi, huyện Dương Minh Châu) là công ty duy nhất của Tây Ninh đạt danh hiệu HVNCLC năm 2014, đây cũng là năm thứ hai liên tiếp công ty đạt danh hiệu này. Sản phẩm kinh doanh chính của công ty Tâm Lan là loại trà túi lọc Tâm Lan được chế biến từ cây lược vàng, hoàn ngọc, cúc hoa, kim ngân v.v... bằng bí quyết riêng.

Để có được sản phẩm chất lượng cao, phục vụ tốt cho sức khoẻ người tiêu dùng, công ty Tâm Lan sử dụng nguồn nguyên liệu tự trồng, không dùng phân hóa học, thuốc trừ sâu...

Dịp này, Hội doanh nghiệp HVNCLC công bố kêt quả khảo sát i2Metrix 2014 (Đề án Khảo sát năng lực Đổi mới-Sáng tạo-Cạnh tranh của doanh nghiệp) và ra mắt Câu lạc bộ Đổi mới sáng tạo.

\section{Đại Dưong}


